\title{
THE PERCEPTUAL TERRITORY MODEL IN THE WATER HOUSES ON STILTS FOUND IN THE HERITAGE AREA ON THE KUIN RIVERBANK IN BANJARMASIN
}

\author{
${ }^{1}$ Regi Kusnadi. ${ }^{2}$ Dr. Giosia Pele Widjaja, S.T., M.T. \\ ${ }^{1}$ Student in the Bachelor's (S-1) Study Program in Architecture \\ at Parahyangan Catholic University \\ ${ }^{2}$ Senior lecturer in the Bachelor's (S-1) Study Program in Architecture \\ at Parahyangan Catholic University
}

\begin{abstract}
The limited amount of land available on the mainland of the Kuin region has triggered the emergence of permanent stilt houses on the river resulting in new settlements as part of the Kuin region. As a matter of fact, these houses on stilts on the riverbank in the Kuin Kampong do not have a well-defined division marker with the air-based space of the river, so that this particular territory is only based on the perception of the individual owners. This research study aims to shed light on territorial behavior and the perceptual territory model to be found at this location. The data collection method was initially conducted by way of direct observation and conducting interviews with various prominent society figures selected from the local community. After the case study object had been selected, in-depth research was conducted into territorial behavior observed in these case studies. The result indicates that there are two perceptual territory models out of the six cases examined based on their territorial attitude. The first one concerns the perceptual territory model pointing toward the front (mainland) up to the road network, and pointing backwards, to the river. On the other hand, on the immediate left and right side of the buildings, they press close on the space owned by their neighbors. The second one comprises the perceptual territory model pointing toward the mainland (reaching the houses across) pointing backwards to the the river, and to the immediate left or right of the buildings.
\end{abstract}

\section{MODEL TERITORI PERSEPTUAL PADA RUMAH PANGGUNG AIR DI KAWASAN PUSAKA TEPI SUNGAI KUIN, BANJARMASIN}

\author{
${ }^{1}$ Regi Kusnadi. ${ }^{2}$ Dr. Giosia Pele Widjaja, S.T., M.T. \\ ${ }^{1}$ Mahasiswa S1 Program Studi Arsitektur Universitas Katolik Parahyangan. \\ 2 Dosen Pembimbing S1 Program Studi Arsitektur Universitas Katolik Parahyangan.
}

\begin{abstract}
Abstrak- Keterbatasan lahan yang ada di daratan kawasan Kuin memicu timbulnya rumah-rumah panggung permanen yang ada di atas sungai, sehingga timbul permukiman baru yang menjadi bagian dari kawasan Kuin tersebut. Pada kenyataanya rumah-rumah panggung air di tepian sungai Kampung Kuin tidak memiliki pembatas yang jelas terhadap ruang air (sungai) sehingga teritori yang ada pada ruang air rumah-rumah tersebut hanya sebagai persepsi dari masing-masing pemilik rumah.
\end{abstract}

\footnotetext{
${ }^{1}$ Corresponding Author: regikusnadi@gmail.com
} 
Penelitian ini bertujuan untuk mengungkap perilaku teritorialitas dan model teritori perseptual yang terdapat pada rumah panggung air di tepian Sungai Kuin. Metode pengumpulan data awal dilakukan melalui observasi langsung dan melakukan wawancara kepada tokoh - tokoh masyarakat. Kemudian selanjutnya mengambil objek kasus studi sehingga diteliti secara mendalam tentang perilaku teritorialitas yang terjadi pada kasus-kasus tersebut.

Pada penelitian ini terungkap bahwa terdapat dua model teritori perseptual dari keenam kasus yang diteliti berdasarkan perilaku teritorialitasnya. Model pertama adalah model teritori perseptual yang mengarah ke arah depan (darat) sampai dengan badan jalan, dan ke arah belakang (sungai). Sedangkan pada samping kiri dan kanan bangunan berhimpitan dengan ruang kepemilikan tetangga. Model kedua adalah model teritori perseptual yang mengarah ke darat (sampai dengan rumah yang ada diseberangnya), ke arah belakang (sungai) dan mengarah ke samping kiri atau kanan bangunan.

Kata Kunci: Teritori, Teritori Perseptual, Teritorialitas, Budaya bermukim

\section{PENDAHULUAN}

Banjarmasin dikenal dengan berbagai keunikan yang terdiri dari keindahan alam, peninggalan-peninggalan, sejarah, adat istiadat, dan budayanya. Berbagai keunikan khas kota Banjarmasin telah mengakar dan mendarah daging pada masyarakat Banjarmasin khususnya budaya air, sehingga telah menjadi identitas yang kuat bagi masyarakatnya. Budaya tersebut sangat penting untuk dilestarikan dan dijaga baik oleh masyarakat Banjarmasin, pemerintah, maupun para pendatang agar kelak tetap menjadi identitas yang kuat bagi kota Banjarmasin. Dalam upaya mengembangkan dan melestarikan budaya tersebut, Kota Banjarmasin tergabung kedalam Program Pelestarian dan Pengembangan Kota Pusaka (P3KP) bersama dengan Samarinda, Pontianak, dan Palembang, yang termasuk kedalam Kota Pusaka Tepi Air. Selain itu Banjarmasin termasuk kedalam salah satu dari 33 kota yang tergabung dalam Jaringan Kota Pusaka Indonesia (JKPI). Kota pusaka merupakan kota yang memiliki keunggulan dan keunikan dari segi alam (Pusaka Alam), bangunan peninggalan bersejarah yang masih bisa disaksikan keberadaannya (Pusaka Ragawi), dan saujana atau cultural lanscape (Pusaka Nonragawi).

Lahirnya Kota Banjarmasin tidak terlepas dari keberadaan kawasan Kuin. Di sungai Kuin ini dulunya terdapat Kerajaan Banjar yang menjadi tonggak awal terbentuknya kota Banjarmasin. Di kawasan tersebut terdapat peninggalan penting yaitu Makam sultan suriansyah, Mesjid Sultan Suriansyah, Kampung Kuin, dan Pasar Terapung Kuin yang menjadi destinasi wisata para turis. Dari peninggalan dan objek-objek wisata tersebut maka Kawasan kuin ditetapkan sebagai kawasan yang akan dikembangkan dan dilestarikan oleh pemerintah setempat untuk mendukung Kota Banjarmasin sebagai kota Pusaka.

Rumah-rumah masyarakat tepian sungai Kuin sebagian besar memiliki dua muka rumah, yaitu muka rumah yang menghadap ke darat dan muka rumah yang menghadap ke sungai. Disisi lain setiap rumah yang ada memiliki teritori masing-masing, baik teritori terhadap ruang darat maupun teritori terhadap ruang air (sungai). Keberadaan teritori tersebut dapat ditunjukan melalui perilaku teritorialitas yang terdiri dari perilaku okupasi, perilaku kontrol akses, perilaku mempertahankan batas, dan perilaku penandaan batas.

Robbert Sommer mengemukaan bahwa "Teritory is visible, stationary, tends to be home centered, regulating who will interact". Hal tersebut menyatakan bahwa teritori memiliki batas terhadap ruang. Pele Widjaja (2007) membagi teritori berdasarkan tiga aspek pembentuk teritorialitas yaitu legalitas, aktivitas, dan persepsi. Legalitas yang dimaksud adalah adanya bukti hukum kepemilikan atau bukti hak penggunaan atas suatu tempat. Aspek aktivitas adalah interaksi sosial masyarakat yang terjadi pada suatu lokasi tertentu. Sedangkan aspek persepsi 
yaitu nilai yang berasal dari pemahaman pengguna atau masyarakat mengenai batasan teritorialitas tersebut.

Pada kenyataanya rumah-rumah panggung tepi sungai Kuin berada di atas sungai dan tidak memiliki pembatas yang jelas terhadap ruang air (sungai) sehingga teritori yang ada pada ruang air rumah-rumah tersebut hanya sebagai persepsi dari masing-masing pemilik rumah.

Hal yang menarik lainnya adalah tidak ada kepemilikan secara legal dari setiap rumah maupun teritorinya. Masyarakat Kuin yang tinggal di tepian sungai hanya menguasai lahanlahan sungai yang dijadikan sebagai rumah mereka, namun mereka tidak memiliki lahan tersebut. Jika dilihat teritori perseptual masing-masing rumahnya, mereka memiliki teritori yang saling beririsan satu dengan yang lainnya. Irisan teritori perseptual tersebut terjadi di daerah ruang air yang tidak memiliki kejelasan batas secara fisik maupun kepemilikan legal. Berdasarkan fenomena tersebut maka timbul pertanyaan penelitian tentang seperti apakah perilaku teritorial dari para penghuni rumah panggung air di tepian Sungai Kuin dan seperti apakah model teritori perseptual dari rumah panggung air di tepian Sungai Kuin.

Tujuan dari penelitian ini adalah menjabarkan perilaku teritorialitas dan model teritori perseptual dari masing-masing pemilik rumah di tepian sungai Kuin. Sehingga dapat Memberikan informasi mengenai perilaku teritorialitas dan model teritori perseptual yang terjadi pada ruang-ruang air rumah panggung di kawasan tepian sungai Kuin. Pada akhirnya informasi tersebut dapat menjadi referensi bagi pembaca dan menjadi acuan untuk pengembangan dan pelestarian kawasan Pusaka di tepian sungai Kuin yang terlihat dari budaya bermukim masyarakat setempat.

\section{KAJIAN TEORI}

Teritori dalam Unity of Study yang dikemumkakan Irwin Altman (1973) merupakan bagian dari behavioral process. Berikut adalah kajian teoritik yang berkaitan dengan teritorialitas rumah.

\subsection{TERITORIALITAS}

Robert Sommer (Gifford 1987) mengemukakan bahwa ruang personal ialah suatu area batas yang tidak telihat yang mengelilingi tubuh manusia untuk membatasi agar orang asing tidak dapat masuk atau mengganggu. Edward T Hall (1966) mengemukakan bahwa ada empat macam derajat ruang personal antara lain jarak inti, jarak personal, jarak sosial dan jarak public.

Sedangkan teritori sangatlah berkaitan dengan teritorialitas. Teritori dapat didefinisikan sebagai tempat atau keberadaannya, sedangkan teritorialtas merupakan perilaku yang menegaskan keberadaan tempat tersebut. 


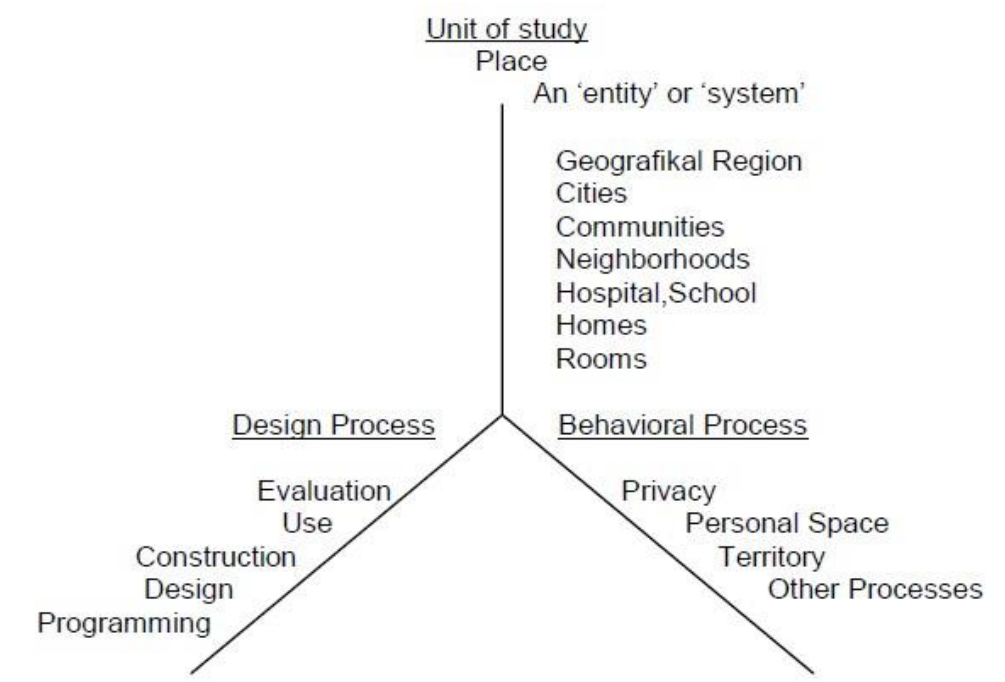

Figur 2. Unity of Study

Sumber: Ruang dan Perilaku, Suatu kajian arsitektural (Hadinugroho 2002)

Diagram diatas merupakan penjelasan yang dikemukakan oleh Irwin Altman (1973) yang memberikan gambaran letak pokok bahasan dari personal space dan teritorialitas. Pele Widjaja (2007) memberikan perbedaan secara jelas antara personal space dan territory bahwa personal space merupakan wilayahnya yang berpindah-pindah sesuai dengan tubuh seseorang, sedangkan teritori wilayahnya menetap, tidak dapat berubah-ubah, dan ada didalam suatu daerah.

\subsection{TERITORIALITAS DOMESTIK RUMAH}

Teritori domestik rumah merupakan tempat yang terlindungi secara legal dan oleh karenanya ada kewenangan yang jelas di dalamnya untuk mengontrol teritori. Berdasarkan hal tersebut, teritori domestik dapat diartikan sebagai wilayah yang ada di lingkungan rumah dalam mewadahi aktivitas aktivitas domestik rumah. Terdapat tiga aspek pembentuk teritorialitas domestik rumah yang dikemukakan oleh Pele Widjaja (2007) yaitu:(1) Aspek Legalitas; Legalitas yang dimaksud adalah adanya bukti hukum kepemilikan atau bukti hak penggunaan atas suatu tempat. (2) Aspek Aktivitas (fungsional); Interaksi sosial masyarakat yang terjadi pada suatau lokasi tertentu, dapat dilihat berdasarkan kegiatan yang terjadi. (3) Aspek Persepsi; Nilai yang berasal dari pemahaman pengguna atau masyarkat mengenai batas teritorialitas itu sendiri.

Teritori dapat dinyatakan secara nyata jika dilihat melalui empat perilaku teritori ini, yaitu:

Penguasaan Tempat (okupasi)

David Stea menyatakan bahwa Perilau teritorialitas adalah menunjukkan okupasi dan penempatan dari sebuah ruang. Dan ketika diperlukan akan melindunginya terhadap gangguan dari luar. Tujuannya dari okupasi adalah untuk (klaim) bahwa suatu ruang dan atau objek objek yang ada di dalamnya sebagai teritorinya. Tindakan penguasaan tempat ditentukan berdasarkan siapa yang secara nyata, menempatkan suatu tempat, menegaskan batas-batas, da melarnag pihak lain untk masuk kedalam teritorinya.

(2) Kontrol akses

Territory is visible, stationary, tends to be home centered, regulating who will interact. (Robert Sommer, 1969). Teritori mengontrol masukan dari dunia diluar teritori, misalnya 
dengan penggunaan papan "No Trespassing" atau "Jangan Lewat Disini" akan membuat batasan yang jelas sekaligus membuat identitas teritory.(Edney, 1976). Tujuan kontrol akses adalah mengatur apa dan siapa yang bisa masuk teritorinya dan atau harus tetap berada di luar teritorinya.

(3) Pelanggaran dan penjagaan tempat (mempertahankan teritori)

Teritori adalah ruang batas dimana seseorang atau kelompok gunakan dan melindunginya sebagai ruang yang dipelihara (Pastalan, 1970). Sedangkan (Sommer dan Becker, 1969) menyatakan bahwa teritorialitas merupakan sikap perlindungan dari gangguan. (lynman and Scoot, 1967) memberikan paparan lebih jelas dari pengertian teritorialitas tersebut yaitu teritorialitas melibatkan usaha untuk mengontrol ruang. Gangguan dapat terjadi dari perusakan, invasi, kontaminasi, dan reaksi perlindungan dapat melibatkan pembelaan terhadap tanah, isolasi, atapun dengan bercakap cakap.

(4) Penandaan batas: demarkasi dan personalisasi

Robert Sommer (1969) menyatakan bahwa "Territory is visible, stationary, tends to be home centered, regulating who will interact." Pernyataan tersebut memberikan definisi bahwa teritori merupakan suatau hal yang terlihat sehingga dapat memberikan penanda batas dari teritori, baik secara nyata mauapun tidak nyata. Secara eksplisit dapat terlihat dengan penempatan, ukuran, skala, enclosure, dan material, sedangkan secara Implisit dapat terlihat dari kebiasaan, penggunaan praktis, dan kesepakatan-kesepakatan.

Beberapa faktor yang mempengaruhi teritorialitas adalah: (1) Faktor Personal, (2) Faktor Situasional, dan (3) Faktor Latar Budaya.

\subsection{TERITORI PERSEPTUAL}

Pele Widjaja (2007) menjelaskan bahwa teritori perseptual adalah nilai yang berasal dari pemahaman pengguna atau masyarakat mengenai batas teritorialitas itu sendiri. Teritori perseptual ini dapat berupa ekspansi ruang yang terjadi terhadap teritori legal dan fungsionalnya, dapat pula sama dengan teriroi legal dan fungsionalnya. Teritori perseptual dapat dilihat berdasarkan beberapa kategori sepert: (1) Indikator ruang perseptual, seperti : Perilaku membersihkan secara rutin wilayah tertentu, memberikan penghijaun terhadap wilayah tertentu, memberikan penerangan terhadap wilayah tertentu, dll. (2) Respon terhadap gangguan teritori, seperti: Merespon jika orang asing masuk dan melintasi wilayah tertentu, merespon jika orang asing memarkirkan kendaraan pada wilayah tertentu, merespon jika orang asing menempatkan barang pada wilayah tertentu, dll.

\section{ANALISA}

\subsection{RUMAH PANGGUNG DI KAWASAN TEPIAN SUNGAI KUIN}

Penelitian ini berfokus pada rumah panggung air yang berada di pemukiman tepian sungai Kuin, Kampung Kuin, Kota Banjarmasin, Provinsi Kalimantan selatan. Jangka waktu penelitian sekitar 4 bulan dari bulan Januari 2016 hingga bulan Mei 2016. Lokasi tersebut dipilih karena permukiman tersebut merupakan permukiman yang berdekatan dengan kawasan Pusaka Banjarmasin yaitu Masjid Sultan Suriansyah dan Makam Sultan Suriansyah dan memiliki keunikan dengan keberadaannya yang ada di atas sungai Kuin. 


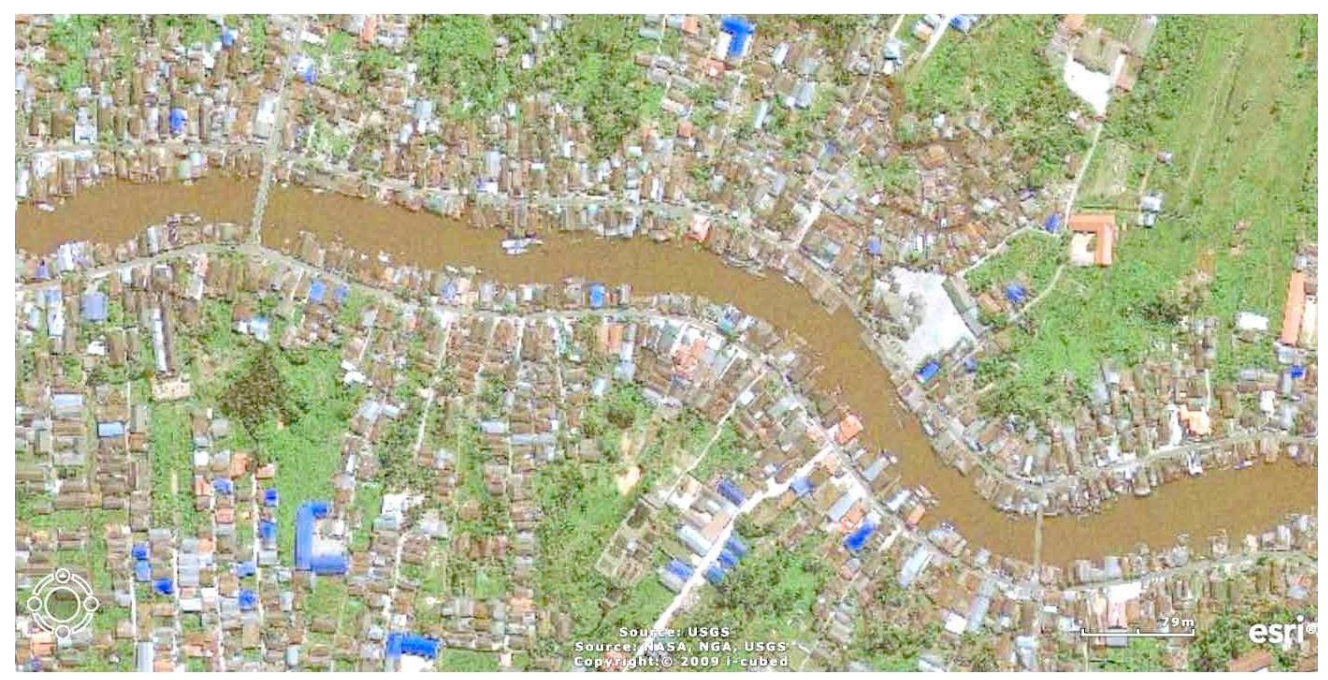

Figur 2. Peta orientasi Kawasan Kuin

Sumber: ArcGIS, 2009

\subsection{METODOLOGI}

Penelitian ini menggunakan metode kualitatif dengan melalui observasi lapangan. Menganalisis tentang perilaku teritorialitas dan model teritori perseptual yang terjadi pada rumah panggung air di kawasan Sungai Kuin.

Pada penelitian ini, metoda analisa data yang digunakan adalah deskriptif - komparatif - interpretatif. Tahap dan proses analisis meliputi tahapan: (1) Tahap 1 Pengolahan Data, (2) Tahap 2 Penyajian Data, (3) Tahap 3 Interpretasi Data, dan (4) Tahap 4 Penarikan Kesimpulan.

\subsection{GAMBARAN UMUM RUMAH PANGGUNG AIR KASUS STUDI}

Teritori perseptual dari setiap rumah masyarakat pada dasarnya akan berbeda stu sama lain. Hal itu biasanya dipengaruhi baik oleh faktor situasional (besar atau kecilnya lahan, kondisi lingkungan sekitar, kondisi masyarakat sekitar), Faktor personal (pekerjaan, usia, suku, pendatang/penduduk asli, ekonomi, agama), dan faktor Latar budaya (kebiasaan masyarakat). Jika dilihat dari faktor-faktor tersebut, maka kasus ini dipilih berdasarkan dengan kegiatan ekonomi yang berada di rumahnya, siapa yang menghuni rumah-rumah tersebut, hubungan rumah terhadap lingkungan disekitarnya. Semakin besar pengaruh mereka baik secara ekonomi maupu secara kultur budaya yang berlaku disana, maka semakin besar teritori perseptual yang dimiliki oleh rumah tersebut. 


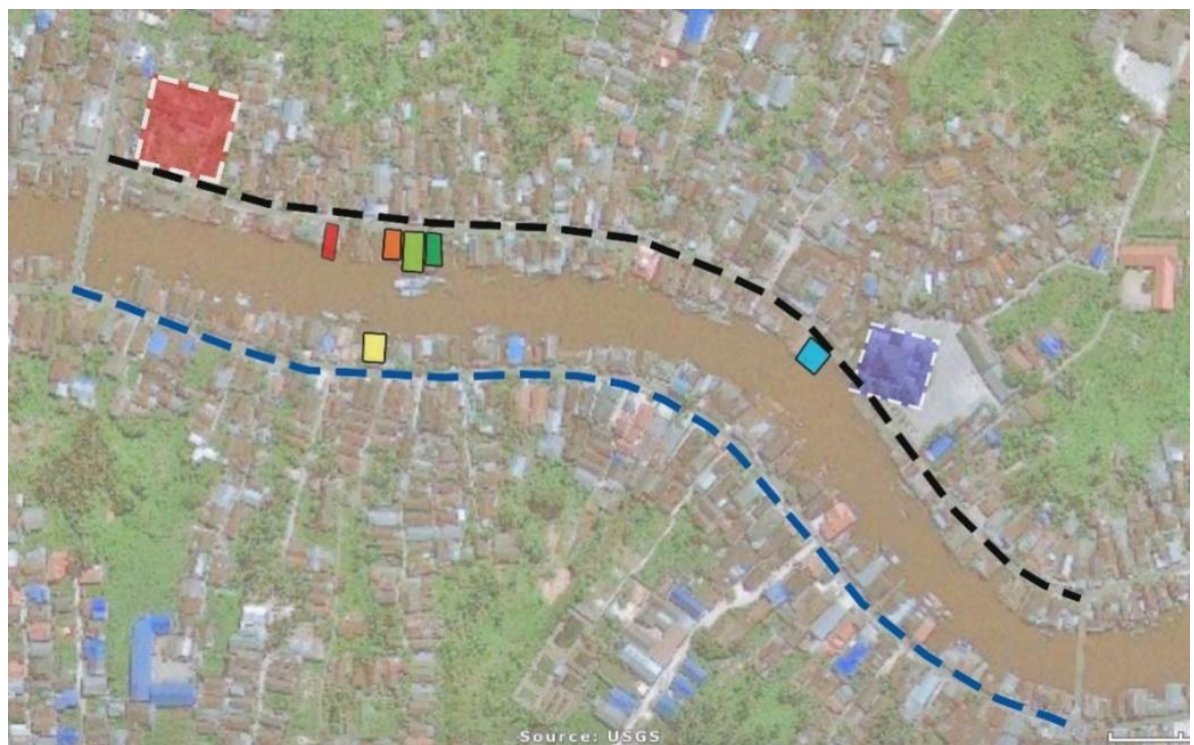

Keterangan:

- Jalan Kuin Utara

- Jalan Kuin selatan

Makam Sultan Suriansyah

Masjid Sultan Suriansyah

Kasus 1 - Rumah Tinggal
Kasus 2 - Rumah komersil home industry

Kasus 3 - Rumah komersil 1

Kasus 4 - Rumah Komersil 2

Kasus 5 - Rumah Komersil 3

Kasus 6 - Rumah Komersil 4

Figur 3. Peta Kasus Rumah Panggung Air di Kawasan Kuin

Sumber: Peta ArcGIS, 2009

Tabel 1. Objek Kasus Studi Rumah Panggung Air di Tepian Sungai Kuin
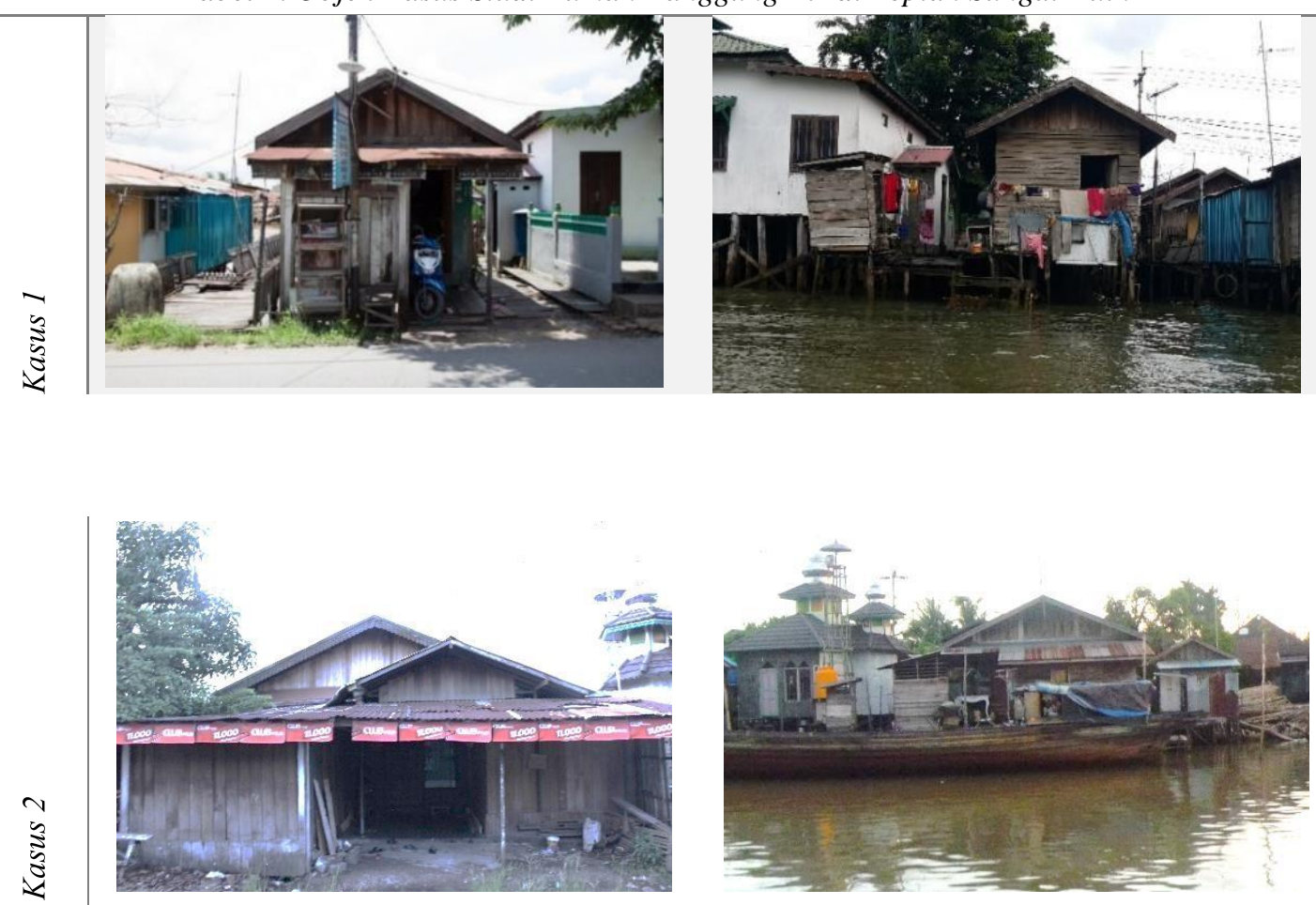


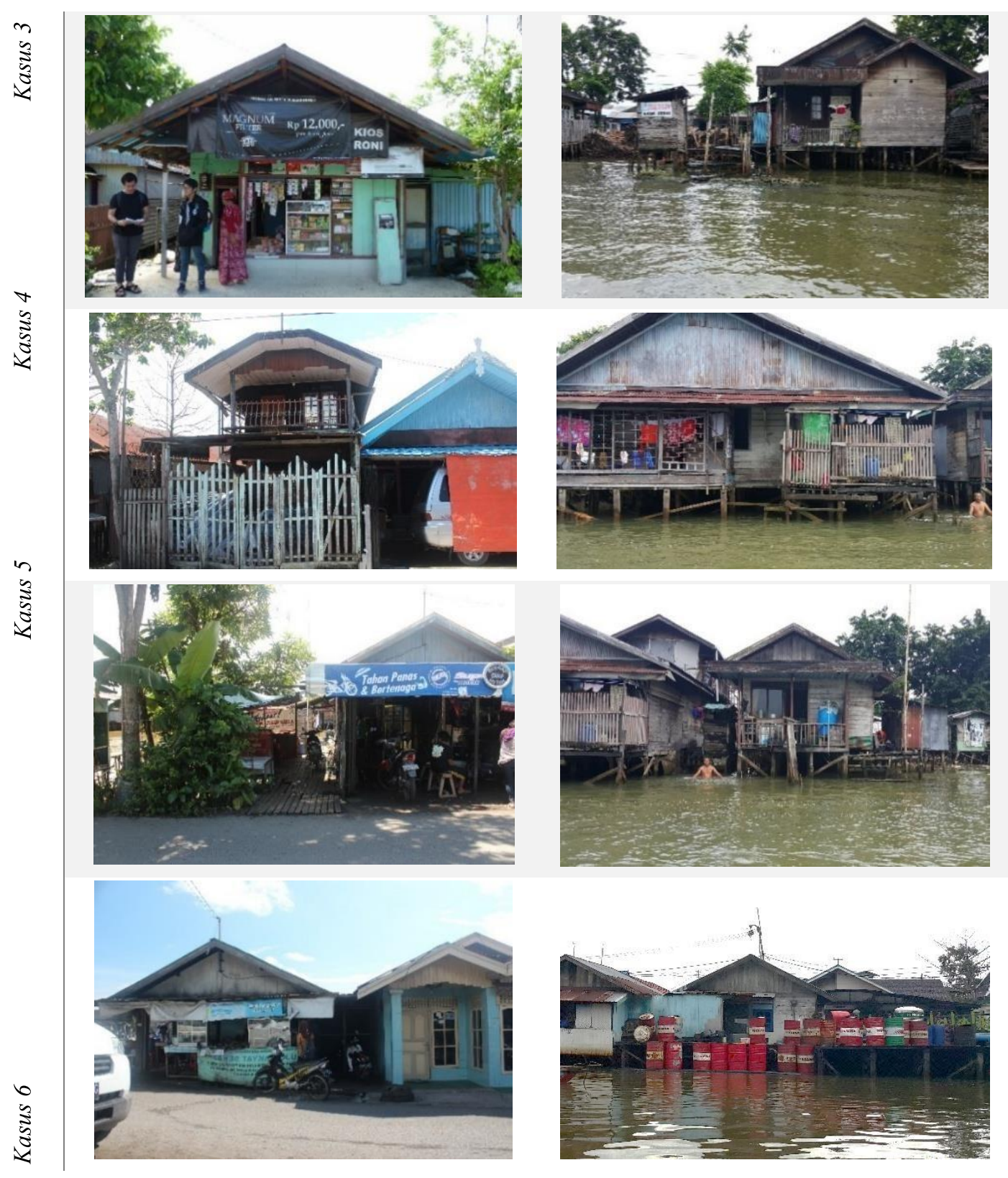

\subsection{TERITORI PERSEPTUAL RUMAH PANGGUNG AIR}

Pele Widjaja (2007) menyatakan bahwa Teritori Perseptual merupakan nilai yang berasal dari pemahaman pengguna atau masyarakat mengenai batas teritorialitas itu sendiri. Teritori perseptual dapat berada di area ruang kepemilikan maupun diluar ruang kepemilikan mereka sesuai dengan persepsi atau pemahaman dari pengguna dan masyarakatnya. Pada penelitian kali ini, Teritori pereptual tersebut diungkap berdasarkan Ruang batas dan arahnya yang akan dijelaskan pada sub bab dibawah ini.

\subsubsection{RUANG DAN BATAS TERITORI PERSPETUAL}

Rumah-rumah panggung air yang berada di Tepian sungai Kuin menunjukkan teritori perseptual melalui tiga perilaku teritorialitas yaitu perilaku okupasi, perilaku kontrol akses, dan perilaku ekspansi teritori yang masing masnig dari ketiga perilaku tersebut membentuk ruang dan batas. Teritori perseptual yang terbentuk secara keseluruhan pada rumahrumah kasus 
tersebut memiliki banyak varian berbeda sesuai dengan faktor personal, situasional, dan latar budaya yang mempengaruhi perilaku teritorialitas tersebut.

Tabel 2. Ruang dan Batas Teritori Perseptual

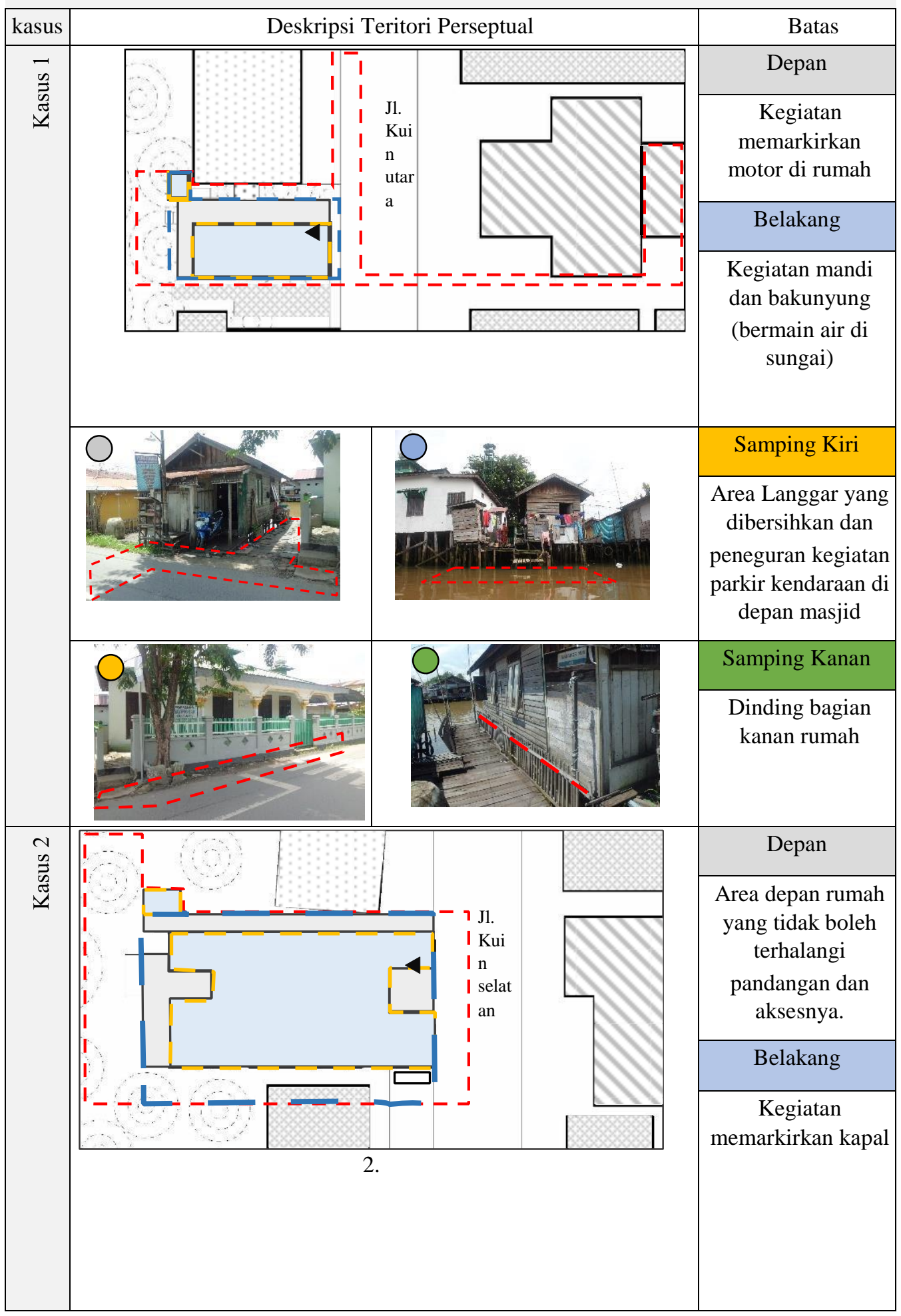




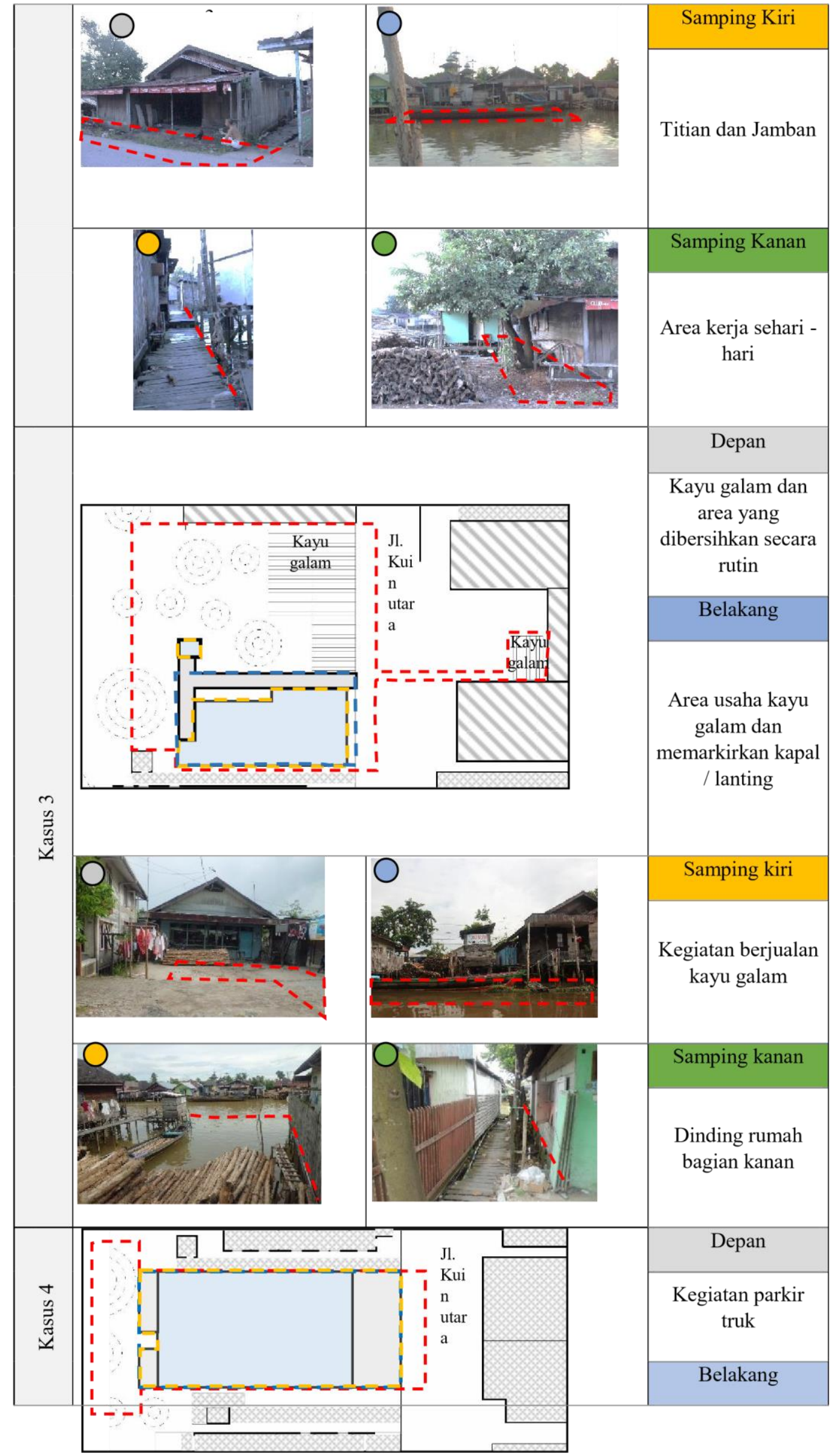




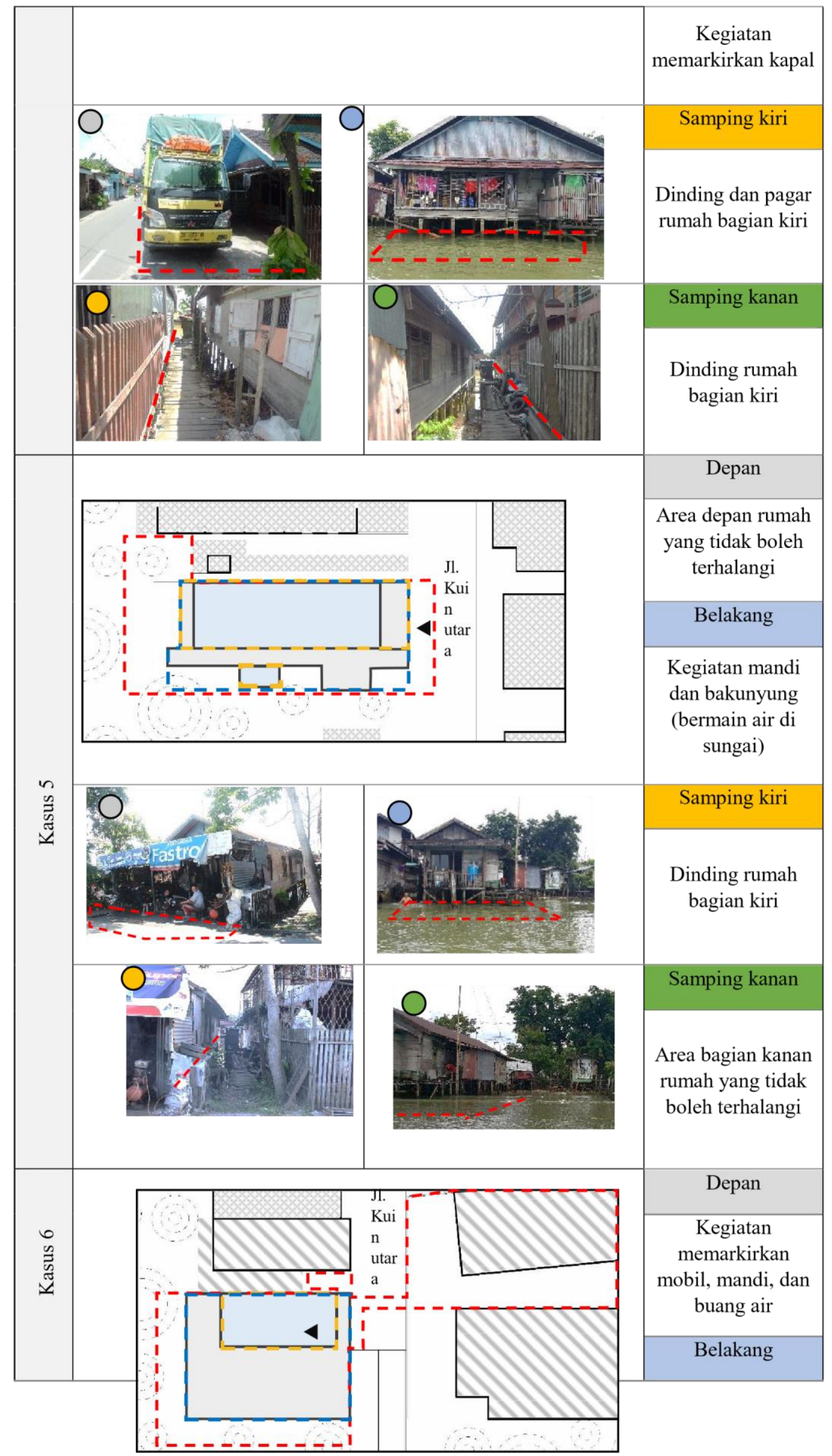




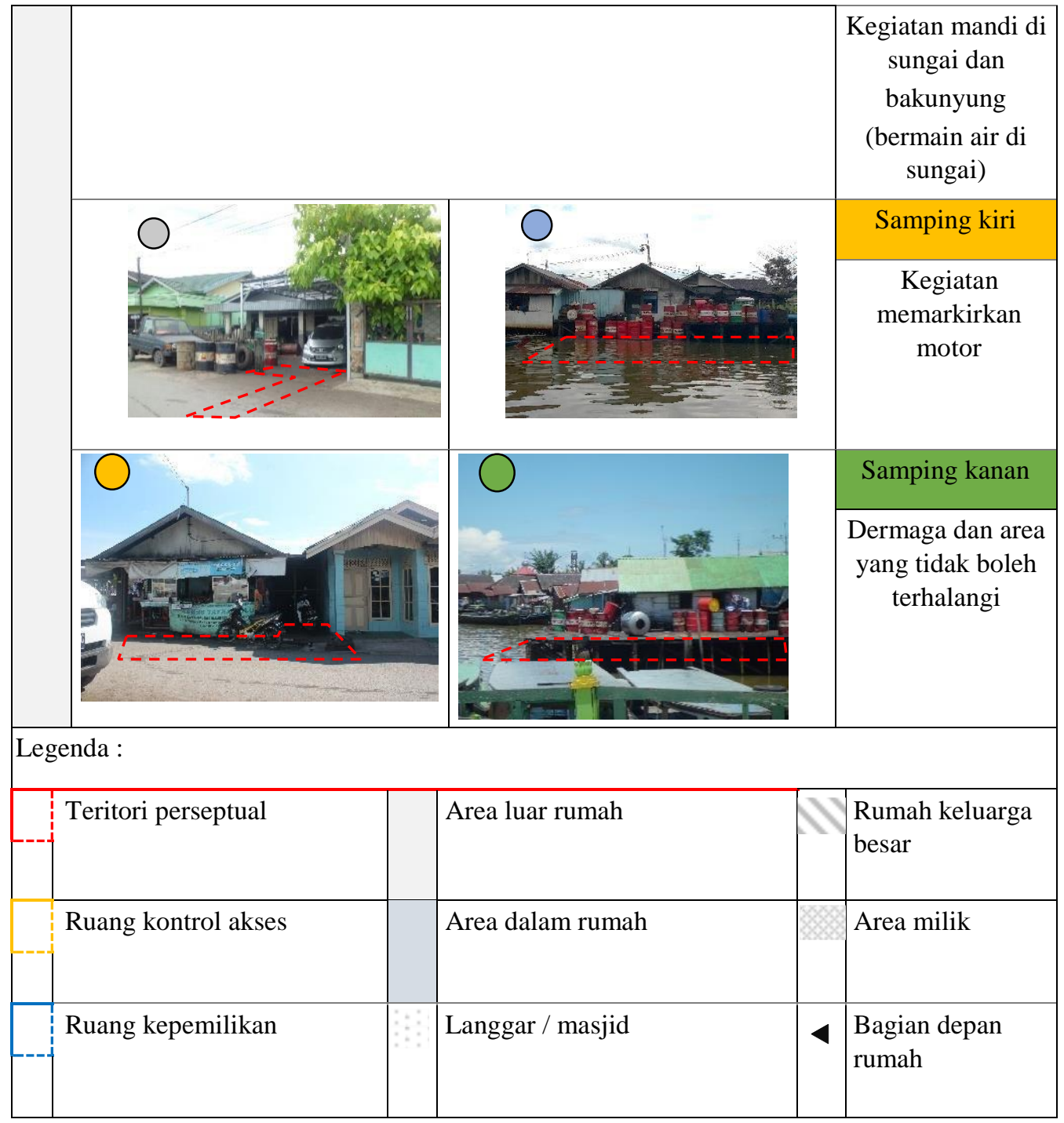

Dapat dilihat dari tabel 6.1 ruang dan batas yang dimiliki setiap kasusnya menunjukkan bahwa batas teritori perseptual bagian kiri dan kanan bangunan cenderung berhimpit dan berada di dinding rumah mereka sehingga batas tersebut ada didalam ruang kepemilikan sesuai dengan perilaku okupasinya. Pada kasus 2,4, dan 5 terlihat kedua sisi bangunan yang berada di kiri dan kanan berhimpitan langsung dengan ruang kepemilikan tetangga dan dibatasi oleh dinding yang terlihat secara fisik. Kondisinya sangat berbeda pada kasus 1,3, dan 6. Pada kasus ini satu sisi bangunan memiliki batas teritori perseptual yang melebihi ruang kepemilikan dari setiap kasusnya.

Pada bagian depan dan belakang bangunan, setiap kasus memperlihatkan ruang dan batas teritori perseptual yang melebihi ruang kepemilikannya. Namun berbeda dengan kasus 1 , 3, dan 6. Faktor situasional keberadaan keluarga yang ada disekitar rumah menjadikan penghuni rumah pada kasus - kasus tersebut leluasa untuk melakukan ekspansi teritori kearah rumah seberang yang berada bagaian darat.

\subsubsection{ARAH TERITORI PERSEPTUAL}

Teritori perseptual dari setiap rumah kasus studi memiliki arah - arah yang berbeda namun cenderung memiliki kesamaan yaitu arah ekspansi teritori ke depan yang mengarah ke 
jalan dan ekspansi teritori yang mengarah ke bagian belakang bangunan yaitu sungai. Namun pada beberapa kasus terdapat ekspansi yang mengarah ke samping kiri maupun samping kanan bangunan yang dipengaruhi oleh faktor personal, faktor situasional dan faktor latar budaya setiap kasusnya sehingga membentuk model teritori perseptual yang berbeda. Model teritori perseptual yang mengarah ke depan sangat dipengaruhi oleh keberadaan keluarga yang ada di depannya.

Ekspansi terhadap rumah yang ada diseberang bangunan sangat dipengaruhi oleh proses perwujudan fisik dari setiap kasus yang dijelaksan pada perilaku okupasi. Pada rumah-rumah yang memiliki hubungan langsung antara rumah darat dengan rumah panggung air, mereka cenderung memiliki hubungan kuat baik ditunjukkan dengan kegiatan-kegiatan yang ada, maupun secara kontrol akses visual antara masing-masing rumah.

Tabel 3. Arah Teritori Perseptual Pada Setiap Objek Kasus Studi

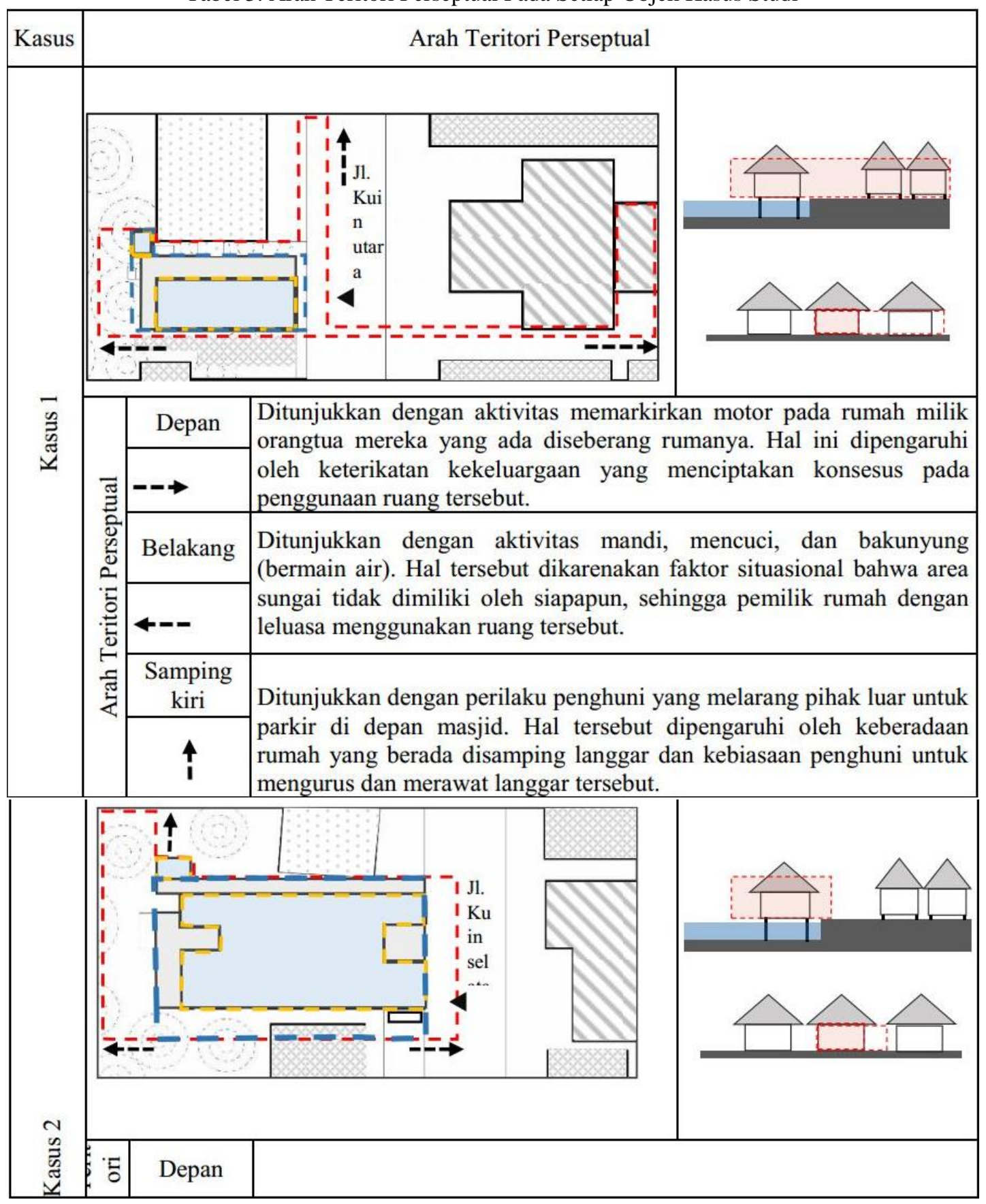




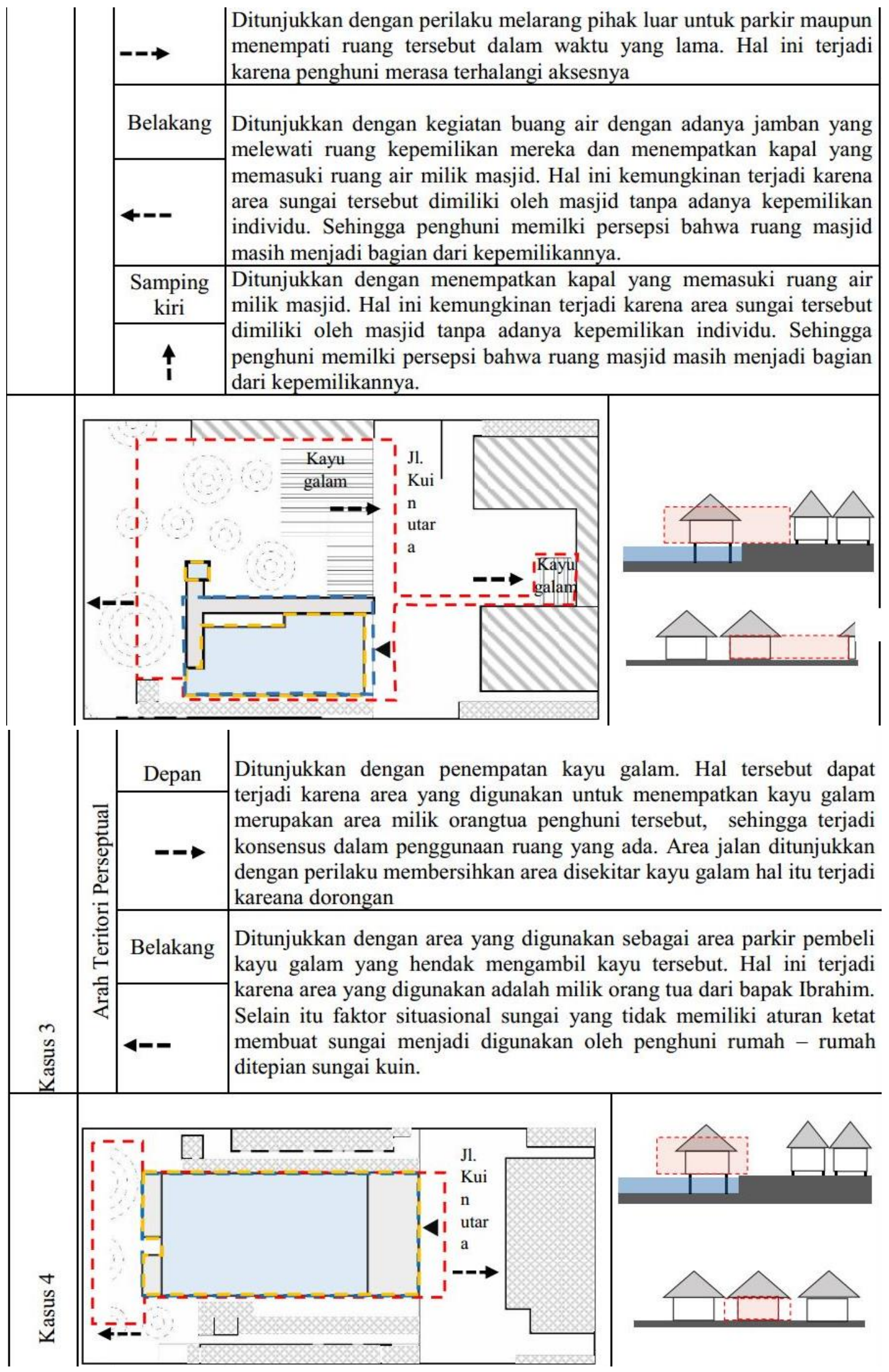




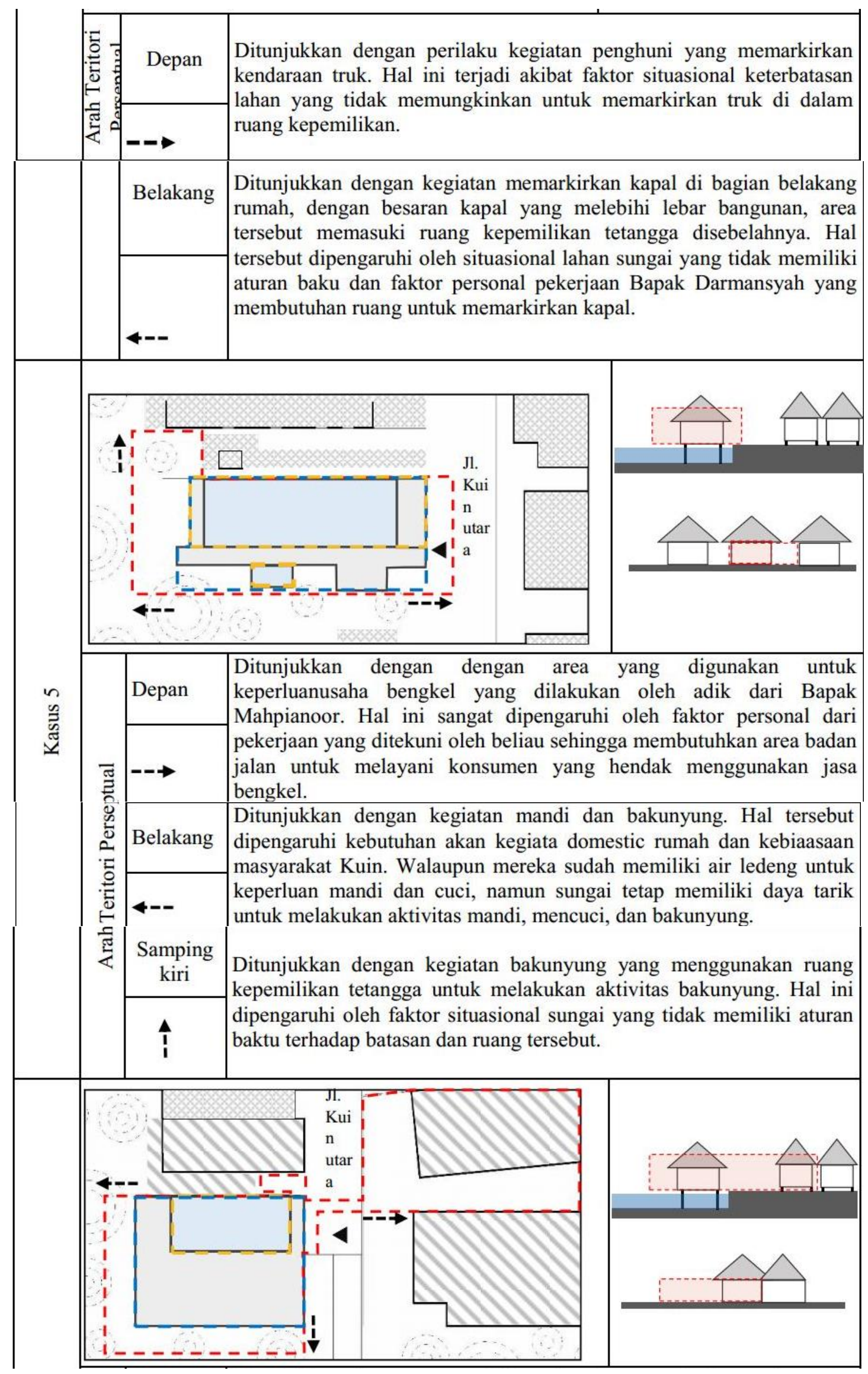




\begin{tabular}{|c|c|c|c|c|c|}
\hline \multirow{5}{*}{$\begin{array}{l}0 \\
\mathscr{0} \\
\tilde{\Xi} \\
\tilde{J} \\
\underline{J}\end{array}$} & \multirow{3}{*}{ 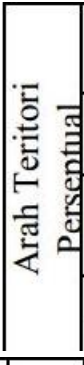 } & Depan & \multicolumn{3}{|c|}{$\begin{array}{l}\text { Ditunjukkan dengan memarkirkan kendaraan pribadi mereka yaitu } \\
\text { mobil dan kegiatan mandi. Hal tersebut sangat dipengaruhi oleh faktor } \\
\text { situasional keluarga sehingga terjadi konsensus ruang dari penghuni } \\
\text { tersebut. }\end{array}$} \\
\hline & & Belakang & \multirow{2}{*}{\multicolumn{3}{|c|}{$\begin{array}{l}\text { Ditunjukkan dengan kegiatan bakunyung dan memarkirkan kapal yang } \\
\text { hendak membeli barang - barang bekas yang dijual oleh penghuninya. } \\
\text { Hal ini dipengaruhi oleh faktor personal perkejaan dari penghuninya } \\
\text { dan faktor situasional sungai yag tidak memiliki aturan baku. }\end{array}$}} \\
\hline & & $4--$ & & & \\
\hline & & $\begin{array}{c}\text { Samping } \\
\text { kanan }\end{array}$ & \multirow{2}{*}{\multicolumn{3}{|c|}{$\begin{array}{l}\text { Ditunjukkan dengan dermaga dan area sungai yang tidak boleh } \\
\text { terhalangi oleh apapun. Hal ini sangat dipengaruhi oleh persepsi dari } \\
\text { penghuninya bahwa area tersebut merupakan akses visual untuk } \\
\text { melihat lingkungan sekitar dan menjadi sarana rekreasi bagi keluarga } \\
\text { mereka. }\end{array}$}} \\
\hline & & I & & & \\
\hline \multicolumn{6}{|c|}{ Legenda : } \\
\hline & \multicolumn{3}{|c|}{ Teritori perseptual } & Area luar rumah & $\begin{array}{l}\text { Rumah keluarga } \\
\text { besar }\end{array}$ \\
\hline 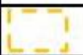 & \multicolumn{3}{|c|}{ Ruang kontrol akses } & Area dalam rumah & Area milik \\
\hline & \multicolumn{3}{|c|}{ Ruang kepemilikan } & Langgar / masjid & Arah depan \\
\hline
\end{tabular}

\section{KESIMPULAN}

Dari pengumpulan data dan analisis yang telah dilakukan secara keseluruhan, maka dapat dibuat beberapa kesimpulan mengenai penelitian ini, antara lain:

(1) Bagaimana perilaku teritorialitas yang terjadi pada rumah panggung air di tepian sungai Kuin?

Perilaku okupasi pada kasus-kasus yang diteliti sangat berkaitan dengan proses perwujudan fisik yang terjadi dari setiap kasus. Keterbatasan lahan yang ada di darat memicu timbulnya rumah - rumah panggung yang berada diatas sungai. Lebar rumah panggung yang berada di atas sungai ditentukan beradasarkan lebar rumah panggung darat yang ada di sebarangnya. Hal tersebut menunjukkan bagaimana faktor situasional keterikatan antar keluarga sangat berpengaruh terhadap perilaku okupasi yang terjadi. Disisi lain jika dilihat berdasarkan legalitasnya, rumah-rumah tersebut hanya memiliki "segel adat" yang berlaku di masyarakat kuin sehingga tidak cukup kuat untuk membuktikannya secara hukum legalalitas negara.

Perilaku kontrol akses dapat dilihat secara fisik maupun secara visual. Secara fisik perilaku kontrol akses ditunjukkan dengan pagar ataupun hanya melalui pintu. Pada rumahrumah yang memiliki lahan kecil, rumah tersebut cenderung tidak memiliki pagar karena berpengaruh terhadap ruang gerak yang semakin kecil dan tidak leluasa. Berbeda dengan kasus rumah yang memiliki lahan cukup besar, rumah-rumah tersebut dapat menggunakan pagar sebagai kontrol akses utama untuk menjaga teritorinya.

Secara visual, jendela ternyata tidak hanya berfungsi sebagai penghawaan dan pencahayaan, namun lebih dari itu berfungsi sebagai media untuk mengawasi area disekitar rumah baik di dalam ruang kepemilikan maupun diluar ruang kepemilikan yang pada persepsinya dianggap sebagai ruang milik mereka. Untuk beberapa kasus yang memiliki keluarga di sekitar rumah, hal tersebut sangat berpengaruh terhadap kontrol visual yang terjadi karena dapat saling mengawasi dan melindungi satu sama lain.

Perilaku ekspansi teritori pada kasus-kasus ini ditunjukan melalui kegiatan yang terjadi diluar ruang kepemilikan dan perilaku mempertahankan teritori. Kegiatan yang cenderung 
terjadi untuk ekspansi ruang bagian depan (darat) adalah parkir kendaraan dan berdagang atau berusaha. Sedangkan pada bagian belakang (sungai) ditunjukkan dengan kegiatan parkir jukung / kapal dan kegiatan servis seperti mandi, mencuci, buang air, dan bakunyung (bermain air di sungai).

Perilaku mempertahankan teritori terlihat dari ruang-ruang yang dibersihkan secara rutin, ruang yang masih leluasa dijadikan area parkir kendaraan, dan ruang-ruang yang tidak boleh terhalangi baik aksesnya secara fisik maupun secara visual. Jika area-area tersebut terjadi gangguan atau tidak sesuai dengan persepsi pemilik rumah tersebut, maka timbul reaksi berupa teguran maupun larangan terhadap orang yang melanggarnya.

Keberadaan keluarga di sekitar rumah kasus-kasus yang diteliti sangat berpengaruh terhadap ekspansi ruang. Ekpansi tersebut ditunjukkan pada kasus 1, 3 dan 6 dengan kegiatankegiatan yang terjadi pada rumah keluarga baik yang ada di samping maupun di seberang rumah setiap kasusnya.

(2) Seperti apakah model teritori perseptual dari rumah panggung air di tepian Sungai Kuin?

Dengan menganalisa melalui tiga perilaku teritorialitas pada ke-enam kasus tersebut, penelitian ini berhasil mengungkap bahwa terdapat dua model teritori perseptual dari keenam kasus yang diteliti. Model pertama yang ditunjukkan oleh kasus 2, 4 dan 5 adalah model teritori perseptual rumah panggung air yang mengarah ke arah depan (darat) sampai dengan badan jalan, dan ke arah belakang (sungai). Kondisi tersebut terjadi karena area sungai dan jalan cenderung tidak dikuasai oleh siapapun kecuali oleh rumah yang berada di depan dan belakangnya. Batas penguasaan yang tidak jelas terhadap sungai maupun badan jalan memungkinkan teritori perseptual tersebut melebar ke arah samping kiri dan samping kanan (overlapping dengan teritori perseptual milik tetangganya). Namun pada samping kiri dan kanan bangunan, model teritori perseptual cenderung berhimpit dengan ruang kepemilikan karena langsung berbatasan dengan ruang kepemilikan tetangganya.

Model kedua yang ditunjukkan oleh kasus 1, 3, dan 6 adalah model teritori perseptual rumah panggung air yang mengarah ke darat (sampai dengan rumah yang ada diseberangnya) dan mengarah ke samping kiri atau kanan bangunan. Hal ini dapat terjadi karena faktor keberadaan keluarga yang berada sekitar rumah kasus-kasus tersebut. Dengan adanya hubungan keterikatan antar keluarga, maka pada kasus-kasus tersebut setiap penghuninya dapat dengan leluasa melakukan aktivitas yang ada di sekitar rumah, tepatnya di area rumah milik keluarga besarnya. Berdasarkan hal tersebut, teritori perseptual yang terbentuk ditunjukkan dengan aktivitas yang berada diluar rumah milik mereka.

Rumah-rumah panggung air tepi sugai kuin timbul berdasarkan kebutuhan akan rumah yang semakin banyak dari masyarakanya. Permukiman ini sudah ada kurang lebih selama 50 tahun yang lalu. Dalam kaitannya dengan Kota Pusaka Banjarmasin, rumah-rumah panggung air ini sudah membudaya dan menjadi bagian yang tidak dapat terpisahkan baik secara ekonomi, sosial, dan budaya masyarakat dengan memiliki perilaku teritorialitas yang seusai dengan karakterisik kawasan Kuin.

Secara keseluruhan penelitian ini berhasil mengungkap bahwa ruang-ruang yang tidak dimiliki oleh rumah panggung air di tepi Sungai Kuin ternyata dikuasi oleh rumah-rumah panggung air tersebut, baik melalui kegiatan yang terjadi, ataupun dengan perilaku kontrol akses dan persepsi masing-masing pemilik rumah. Pada akhirnya ruang-ruang yang dimiliki secara adat maupun yang hanya dikuasai oleh pemilik rumah panggung air pada kasus-kasus yang dipilih dinyatakan sebagai varian teritori perseptualnya yang ada pada permukiman di kawasan tepi Sungai Kuin. 
Dengan maraknya isu tentang penggusuran yang akan menghabiskan rumah-rumah panggung air di tepian Sungai Kuin, diharapkan penelitian ini dapat membantu untuk menjadi salah satu pertimbangan penting dalam perbaikan kualitas permukiman tersebut. Perbaikan ini tentunya memperhatikan perilaku teritorialitas baik terhadap ruang darat yang saling keterikatan dengan rumah milik keluarga didepannya, maupun terhadap sungai yang sudah menjadi kebutuhan dasar bagi masyarakat Kuin. Pada akhirnya dapat mewujudkan permukiman yang layak dan sesuai dengan perilaku teritorialitas masyarakat Kuin.

\section{DAFTAR PUSTAKA}

\section{Buku}

Altman I. (1984). Culture and Environment. Cambridge: Cambridge University Press.

Bell. Paula A (et al). 1978. Environmental Psychology. Philadelphia: W.B. Saunders Company.

Canter, David. (1974). Psychology for Architects. London: Applied Science Publishers Ltd.

Kusliansjah, K. (2015). Konsep Arsitektur Kawasan Sungai Pasang Surut pada Era Pra-Kolonial dan Kolonial di Kota Lama Banjarmasin. Bandung: Universitas Katolik Parahyangan.

Setiawan, Haryadi B. (1996). Arsitektur Lingkungan dan Perilaku. Yogyakarta: PPLH UGM.

Widjaja, Pele. (2007). Teritorialitas Domestik Rumah Pada Dua Kampung Kota di Bandung (tidak dipublikasikan). Disertasi Program Studi Arsitektur ITB.

\section{Jurnal}

Ananto, Sofian D. (2015) Adaptasi Teritorialitas pada Permukiman Horisontal ke dalam Permukiman Vertikal. Bandung: Temu ilmiah IPLBI 2015.

Hadinugroho, Dwi Linda. (2002). Ruang dan Perilaku: Suatu Kajian Arsitektural Medan: USU digital library.

Kasman, Syahriyah, Ananto, Widhianto. (2015) Teritorialitas Masyarakat Perumahan Menengah ke Bawah. Bandung: Temu ilmiah IPLBI 2015.

Mentayani, Ira. Pudarnya Makna Kebudayaan Sungai di Kota Banjarmasin.

Rochgiyanti. (2011). Fungsi Sungai Bagi Masyarakat Di Tepian Sungai Kuin Kota Banjarmasin: Jurnal Komunitas. 